\title{
Leidsche Rijn: Balancing the Compact City with the Randstad Motorway Network
}

\author{
Frank van der Hoeven \\ Delft University of Technology, Faculty of Architecture \\ Netherlands
}

\section{Introduction}

In the mid-1990s, the Dutch economy grew at a pace of 3 to 4 percent annually (CBS, 2009). The use of the country's major infrastructure increased accordingly, and the urban areas in the western part of the country, the Randstad, continued to expand to meet the soaring housing demand. After decades of state intervention, the government started to loosen its grip on local and regional urban development. The government's policy on spatial planning shifted away from the concept of planning new towns to focus on more compact urban development (compacte stad). The policy reasoned that a compact city would have a smaller environmental footprint because of more effective land-use and shorter daily travel distances. With its Fourth Report on Spatial Planning (VROM, 1988: Vierde Nota) and the additional VINEX-report (VROM, 1993: Vierde Nota Extra), the Ministry of Spatial Planning, Housing and the Environment no longer seemed to dictate that one solution that fits all. Rather, it sought to implement developments that suited the regional territorial characteristics and the preferences of the concerned authorities. Thus, Utrecht ended up with the largest VINEX-development in the Netherlands. In fact, Utrecht is the fourth largest city by population in the country, after Amsterdam, Rotterdam and The Hague.

Although the concept of the 'compact city' may be simple, it had deep implications for the relation between infrastructure planning and town planning. Back in the seventies and eighties two major new town developments were built south of Utrecht to house its expanding population. The physical distance between the mother city and its new towns allowed the unobstructed expansion of the national motorway network. In the nineties Utrecht preferred a development that kept its inhabitants close by so they would remain bounded to Utrecht, both economically and socially. The development of Leidsche Rijn with a projected 30.000 housing units sought a close physical relationship with the mother city. For the first time the extending city and the expanding motorway network became at odds with each other. The area between Utrecht and Leidsche Rijn left little space to accommodate a wider A2 motorway and its environmental impact. Encapsulating the A2 motorway in a two kilometre long tunnel was proposed as the most suitable way to integrate the road in the new urban district. With no effective regulation in place and no similar practice to fall back on, the Leidsche Rijn land tunnel broke ground to allow the use of motorway tunnels for a new and promising application: environmental and spatial integration of motorways in urban areas. This chapter focusses on the struggle and trade 
offs in the adjustment between spatial planning and infrastructure planning in one of the key urban development projects in the Netherlands: Leidsche Rijn.

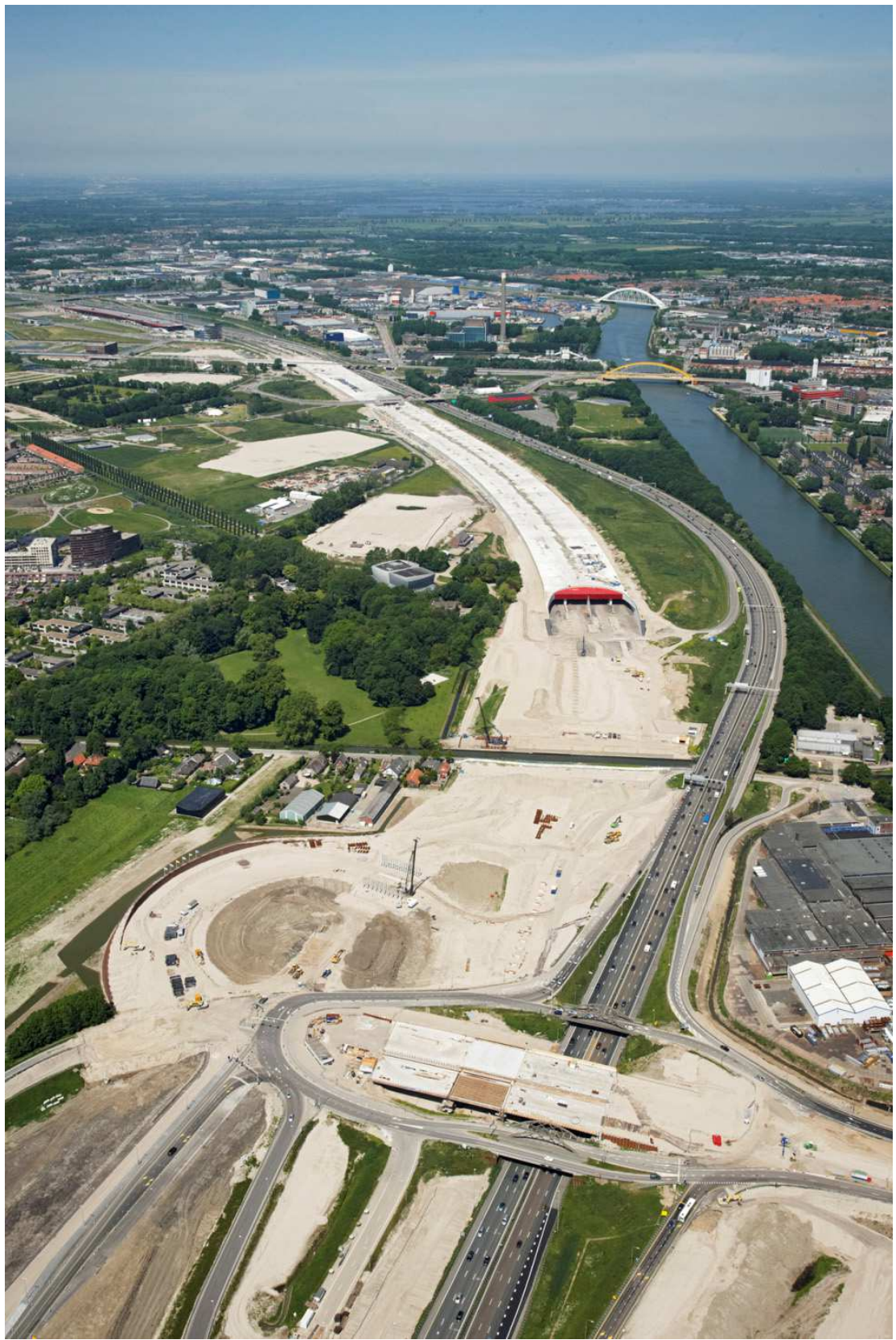

Fig. 1. Aerial photo of the Landtunnel Utrecht. (Gerry Hurkmans, 2009). 


\section{Outline}

This chapter deals with the growing tension between the necessity to widen the Randstad's motorway network and its urban footprint. It poses the question how to integrate large scale infrastructure in urban areas. This design/engineering/planning task requires a multidisciplinary approach, combining insights drawn from urban and spatial planning, civil engineering, safety assessment, environmental impact assessment and governance.

Because most foreign readers aren't familiar with the topography and the spatial development of the western part of the Netherlands three key areas are highlighted first: the Randstad, the Green Heart and Leidsche Rijn. This sets the stage for explaining why Leidsche Rijn is a good indicator for the changes occurring in the leading concepts of urban planning, spatial planning and infrastructure planning in the Netherlands. It allows the discussion of the main concept of the Leidsche Rijn in order to explain why the city wanted to integrate the A2-corridor in the urban development. That integration had deep consequences for the physical shape of that road as it required the construction of a major road tunnel. As soon as the concept for a tunnel was embraced by the local and regional governments the deal started to unravel under pressure safety concerns, voiced by the national government. The safety of the users of the tunnel and the safety of those that would live or work next to it seemed at risk. At this point the chapter moves into an interdisciplinary area where only a few specialist speaks each others professional language. Due to a lack of mutual understanding between politicians, urban planners, safety assessment officers and transport planners the project moved in to a deadlock which took years to resolve.

The storyline is based on the review of many of the relevant policy documents and plans written in the Dutch language on this matter, on in depth interviews with key players in the process and the various environmental and safety assessments. The final form of this chapter is that of a rigorous multidisciplinary case study.

\section{Randstad and Green Heart}

Utrecht is one of the four Dutch cities that jointly constitute the Randstad. The Randstad is the framework commonly used to describe the densely populated western part of the Netherlands. In the mid 1960s that Randstad was discovered by academics from the AngloSaxon world as an alternative model for metropolitan growth. For London, in particular, struggling to contain its large continuous urban area, by the so-called Green Belt, the Randstad seem to demonstrate that a large urban population could be organised in a networked polycentric configuration, and function well at the same time. That idea appealed to writers like Gerald L. Burke (Burke, 2006) and Peter Hall (Hall, 1966, 1977, 1983). The Randstad was seemingly less congested than a classic metropolis and possessed an invaluable asset: the Green Heart.

The simple concept of a large green area surrounded by a ring shaped conurbation settled quickly in the minds of students, practitioners and academics alike. It also helped to place Holland on the map and that seemed necessary. In 1966 Gerald L. Burke already noted that although The Netherlands is known for its city planning, "less widely known are the policies of regional planning which have been developed in the Netherlands since World War II" (Burke, 2006). 
When Gerald L. Burke wrote his book he referred to the brand new Second Report on Spatial Planning (V\&RO, 1966) and to the documents that preceded it. In the late fifties the Netherlands started to formulate its national spatial planning agenda. The 'Working Committee on the Western part of the Country' produced in 1958 its report including the famous plan for the 'schematic structure of the urban ring', a conceptual vision on the spatial structure of Randstad (Berveas et al, 2001). At the end of the fifties it became clear that the Green Heart was being threatened by (sub)urbanisation. Especially the open zones in between the larger cities on the urban ring were at risk. The 'Working Committee on the Western part of the Country' advised to keep the cities in the ring structure separated, both functionally and spatially. The strategy was to apply designated buffer zones between the urban areas and to plan new cities on the outside of the ring as opposed of the inside the ring (in the Green Heart). An increasing set of sophisticated instruments was used to preserve these formal buffers, ranging from land acquisition to legislation (Bervaes et al, 2001). Time was to prove that these buffer zones would be more robust than the Green Heart itself.

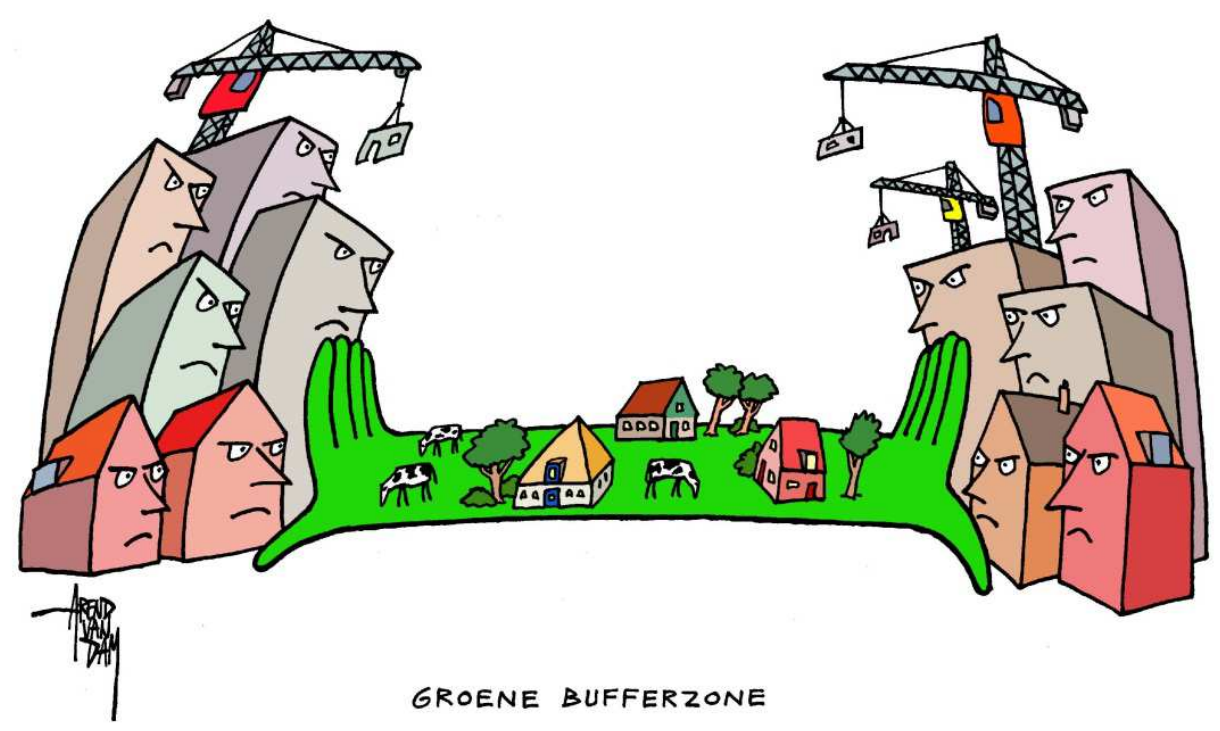

Fig. 2. Green buffer zone (Arend van Dam, 2008)

As soon as the Dutch government adopted the Green Heart concept that same government began two other initiatives that were in direct contradiction to the idea to maintain the Green Heart as an open space. The first initiative was the publication of the structure plan for the national motorway network in 1966 (Dutch: Structuurschema Hoofdwegennet 1966).

It proposed the rollout of a dense grid of motorways over much of The Netherlands including the Green Heart - where ten (!) additional motorways were planned. Secondly, it developed and adopted the 'groeikern' approach. Groeikern (growth municipality) is the Dutch equivalent of the British 'new town' and the French 'ville nouvelle' policies. The 
Dutch government decided to focus urban growth in a limited number of municipalities to give these a specified quantitative task to increase their housing stock, and subsequently their population and urban area.

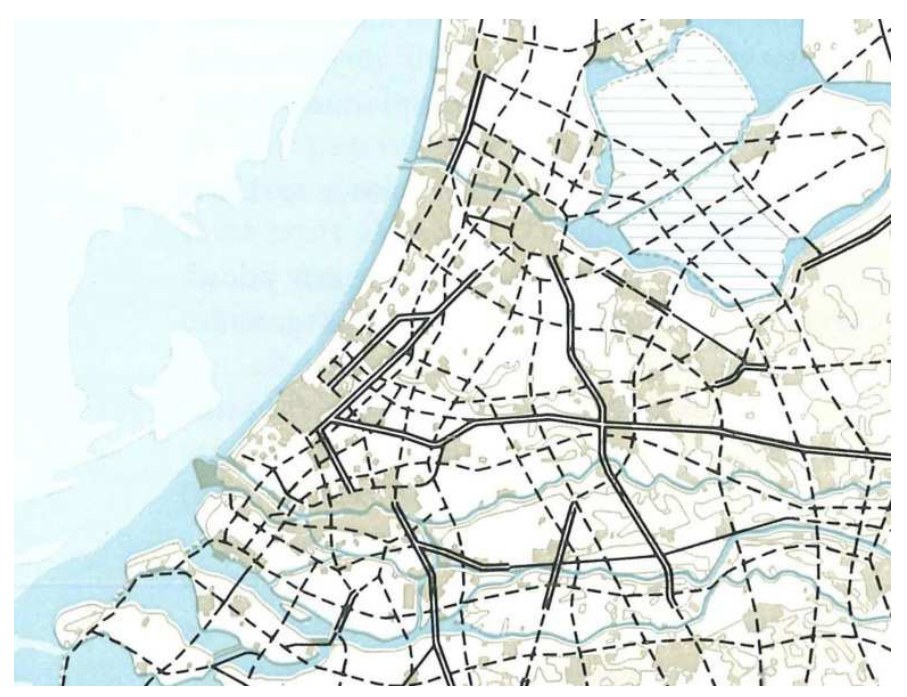

Fig. 3. Structure plan national motorway network 1966 (V\&RO, 1966)

\section{Third and Forth Report on Spatial Planning}

The 'growth municipalities' entered officially the planning stage at the time of the Third Report on Spatial Planning (V\&RO, 1976, 1977). A steep increase of the number of inhabitants in a part of these municipalities can already be traced back a decade earlier. Some of the 'grow municipalities' turned into independent towns; some of them were merely the extension of the larger agglomerations. The Third Report listed eleven official 'growth municipalities'. Each of the four larger cities in the Randstad was outfitted with at least one 'growth municipality' that was firmly situated in the area that was still considered to be an integral part of the Green Heart: Hoofddorp in the Amsterdam region, Zoetermeer in The Hague region, Capelle aan den IJssel in the Rotterdam region and Nieuwegein in the Utrecht region. Most of the roads that were foreseen in the 1966 structure plan for the national motorway network never made it off the drawing board. Motorway construction still made a significant impact on the Green Heart with the construction of the A2 (Amsterdam - Utrecht - Den Bosch), the A4 (Amsterdam - The Hague), the A20 (Rotterdam Gouda), the A67 (Hilversum - Utrecht - Breda), the N11 (Leiden - Bodegraven) and to a lesser extend also the A1 (Amsterdam - Hilversum).

The Forth Report on Spatial Planning (VROM, 1988) and its extended version called VINEX (VROM, 1993) abandoned the 'growth municipality' strategy and introduced the so-called VINEX-extensions. The VINEX-extensions, with its new residential areas at Noordrand (Rotterdam), Ypenburg (The Hague) and Oosterheem (Zoetermeer) and Leidsche Rijn (Utrecht) pushed the envelop of the Green Heart further inwards. No new motorways were planned but most of the existing roads would be widened. At the turn of the century, after 
four decades of spatial planning, the overall concept of how the urban areas, open spaces and infrastructure of the Randstad related to each other had fundamentally changed.

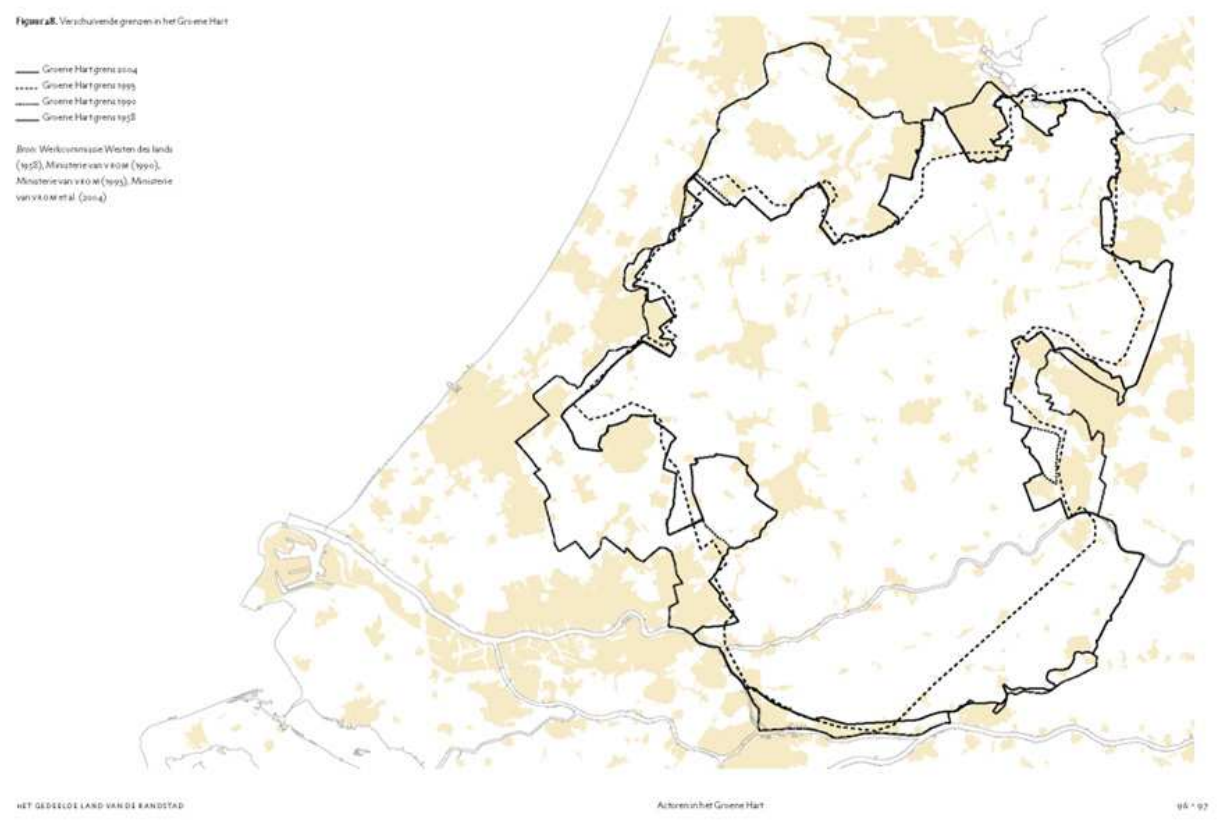

Fig. 4. The shrinking boundaries of the Green Heart (Pieterse et al, 2005)

\section{Leidsche Rijn}

Leidsche Rijn is one of the most prominent products of the VINEX-report and reflects much of the developments that took place elsewhere in the Randstad. Leidsche Rijn expands the city of Utrecht (313.000 inhabitants) with 20 to 30.000 housing units, a large urban park and even larger employment areas. The development annexes the villages of Vleuten en De Meern. By doing so it almost doubles the urban footprint of the municipality of Utrecht. The larger Utrecht region had developed according a decentralised poly-centric model using new towns to accommodate the demand for high quality living in the region. It was a response to the concern that cities would become too large, too congested, too polluted. The Utrecht region witnessed the construction of two successful new towns: Nieuwegein $(61.000$ inhabitants) and Houten (48.000 inhabitants), separated from mother city Utrecht by a orbital motorway. Houten became a poster-boy for sustainable transport with its clever combination of transit-oriented development and a sophisticated bicycle network. The construction of the motorway network that connected the various cities and towns in the decentralised Randstad infrastructure didn't pose any difficulties for development of Nieuwegein and Houten. Motorways were in the 1970s still lean and mean. Their environmental impact was limited while the space between Utrecht and its new towns was superfluous. 
Leidsche Rijn, conceived two decades later, signals in many respects a clear break from previous spatial planning concepts. Leidsche Rijn is based on the compact city concept. That city model assumes that keeping distances within urban regions short will result in environmental benefits through reduced travel(time) and more effective land use. Keeping new developments close to Utrecht meant that city had to develop westwards into the area that was an integral part of the Green Heart since that concept was coined. The Fourth Report on Spatial Planning adjusted the planning border of that Green Heart to allow the development of Hollands largest greenfield development. The ambition to minimise the distance between Leidsche Rijn meant furthermore that the urban development had to make effective use of the space along the A2 motorway, space that would normally be leftover due to the environmental footprint caused by noise, air pollution and risks. Because the capacity of the A2 was insufficient, the road had to be widened from $2 \times 3$ lanes to $2 \times 5$ lanes. Both projects, extending Utrecht and extending the A2 corridor had to take place in one integrated development project.

\section{Masterplan Leidsche Rijn}

In the early 1990s, a young urban planning firm received the commission to develop a master plan for Utrecht's new VINEX development Leidsche Rijn. The office was by then know as Max 1, currently as Maxwan. Maxwan proposed a different direction than most urban planners tended to pursue. Usually planners pay close attention to the environmental constraints of a site and use them as a starting point, trying to keep housing and other soft functions (such as education and care facilities) at a secure distance from major arteries or other producers of noise, air pollution and safety issues. This explains why in the Dutch practice green spaces are often used to fill up the gap between infrastructure and residential areas. But as a result, those green spaces often end up fragmented, noisy, polluted and not well suited to the recreational purposes that green spaces are mostly associated with.
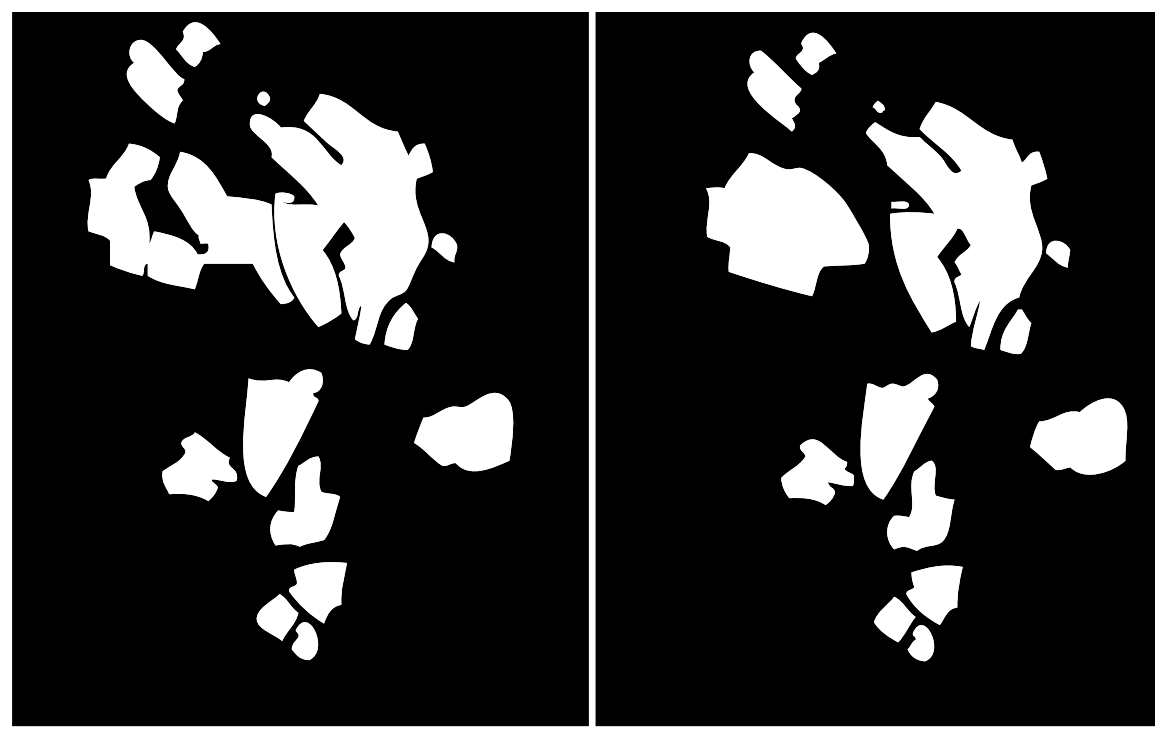

Fig. 5. Leidsche Rijn with (left) and without (right) a tunnel solution (Maxwan, 2009) 
Maxwan proposed to implement an innovative approach, like shifting the course of the motorway while at the same time tunnelling it. The company received that approval, and in 1995 delivered its Masterplan Leidsche Rijn, commissioned by the City of Utrecht. Therefore, the city of Utrecht proposed its Master Plan Leidsche Rijn to contain the noise and air pollution of the A2 motorway with a two-kilometre tunnel situated a few hundred meters from its original alignment in 1995 (Projectbureau Leidsche Rijn, 1995). The tunnel was partly suppressed with the assumption that a tunnel in the local soft soil conditions (with a high ground water level) would be cheaper to build as a 'floating construction' than as a submerged tunnel or as a full-fledged land tunnel. In addition, a suppressed tunnel is beneficial because it does not function as a barrier between the existing city of Utrecht and the new Leidsche Rijn development. Encapsulating the motorway allowed Maxwan to built housing and city centre functions next to the motorway. This allowed to plan a large urban park right at the heart of the development site where all residents could easily access it and not be burdened by noise or air pollution.

\section{Safety concerns and the project's first revision}

Not long after the Masterplan Leidsche Rijn proposed its tunnel solution, concerns were voiced regarding the internal and external safety of the Landtunnel Utrecht that was such an integral part of the overall Master Plan Leidsche Rijn. Safety experts from the Construction Department of the Directorate General for Public Works and Water Management (part of the overall Ministry of Transport, Public Works and Water Management) pointed out that constructing a tunnel in the A2 would violate the existing rules and regulations for the transportation of dangerous goods, especially the transport of liquid flammable gasses, a category that contains predominately Liquefied Petrol Gas or LPG (Rijkswaterstaat Bouwdienst, 1996).

The Netherlands had many road tunnels by the late 20th century, and the majority were motorway tunnels that crossed one of the many waterways in the delta of the Rhine and Meuse rivers. Compared to tunnels in the mountainous parts of Europe, these tunnels are short in length. The fully enclosed sections of these tunnels often measure less than thousand metres. On the other hand, these tunnels tend to be rather wide. Tunnels with four lanes in each direction are not the exceptions. Their vulnerability does not stem from their length, but from the large volume of traffic that uses them and from their strategic position under water.

The general rule in the Netherlands is that all transportation of dangerous goods occurs on the motorway network because motorways provide higher levels of road safety. There is an exception to this rule. When a tunnel can be bypassed by using a bridge, then the use of that bridge is preferable. The bridge should be used, even if it increases the external risk for local inhabitants. This exception exists because of the economic risks involved in losing a tunnel. A scenario that includes the transport of dangerous goods could develop into an accident that could effectively put a tunnel permanently out of use. A truck carrying LPG could cause a problem such as a boiling liquid expanding vapour explosion (BLEVE). Although the chance that such a scenario develops may be remote, the possible impact of the scenario is devastating and, therefore, poses a considerable risk (Molag, 1998). It is unrealistic to expect that an underwater tunnel damaged in such an event could be repaired. It would become necessary to build a new one. Such a scenario could leave the Rotterdam Harbour, 
for instance, without a decent road connection for a period of four years. The indirect economic damage would be so extensive that the ministry is not willing to take any chances. Thus, it banned the transportation of the most damaging dangerous goods from its tunnels (Directie Transportveiligheid, 1997). The multifunctional tunnel at Leidsche Rijn seemed to violate this regulation. The development of the Leidsche Rijn project, however, was in such an advanced stage that simply banning the tunnel was no longer feasible politically. A different solution had to be developed.

In response to the safety concerns regarding the transport of dangerous goods, the Ministry of Transport, Public Works and Water Management opted to replace the full tunnel with a series of three shorter tunnels. This would reduce the impact of the most extreme anticipated scenarios on the A2 motorway users. Shorter tunnels contain fewer people, thus reducing the maximum number of potential causalities. The Ministry also opposed the idea of a 'floating tunnel' along a new alignment. The idea was not considered technically feasible. A fully submerged tunnel was out of the question because of the high ground water level that increases the cost to build such a structure. The construction of aboveground tunnels next to the current A2 emerged as the preferable solution.

The tight integration between urban development and road expansion required the Master Plan to be adjusted. Breaking up the tunnel meant that the environmental impact of the motorway would be felt in the area, noise and air pollution would be especially prominent. Raising the roof of the tunnel to a level of 6.5 metres above the surrounding area meant that the tunnel would function as a physical barrier. A preliminary concept responding to these issues, the Creative Alternative Integration A2 / Leidsche Rijn, was subsequently included in a revised master plan: the Ontwikkelingsvisie Leidsche Rijn Utrecht (Projectbureau Leidsche Rijn, 1996). It became the first major revision of the Masterplan and the tunnel concept.
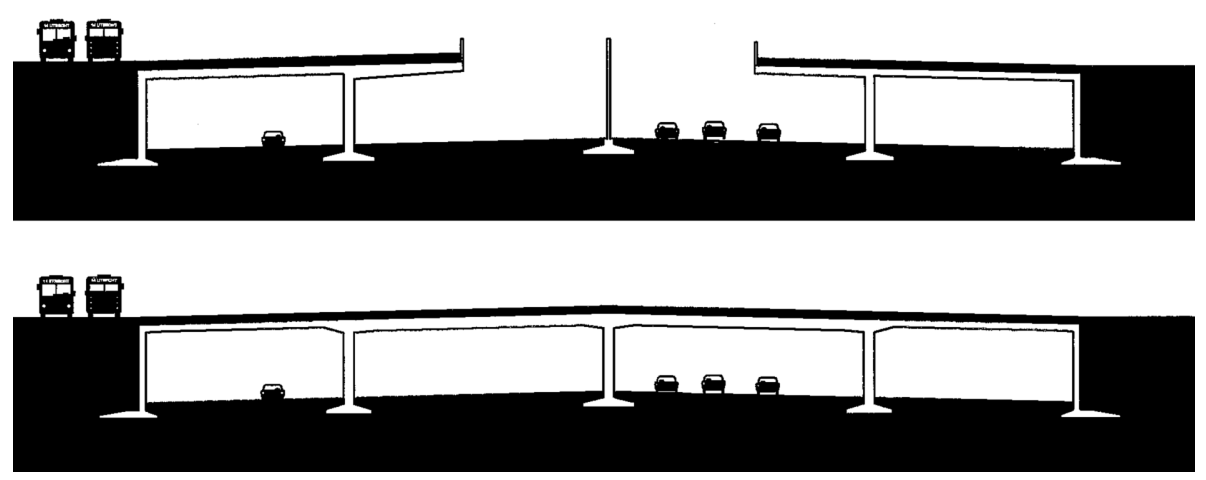

Fig. 6. Creative Alternative: cross-sections (Maxwan, 1998).

The 'Creative Alternative' consisted of three short tunnels, measuring $450 \mathrm{~m}, 408 \mathrm{~m}$ and 188 $\mathrm{m}$. The Ministry did not allow housing to be built on top of these sections; instead, the area is designated for recreational purposes. Noise barriers would have to be used to reduce the environmental impact along the open sections. 


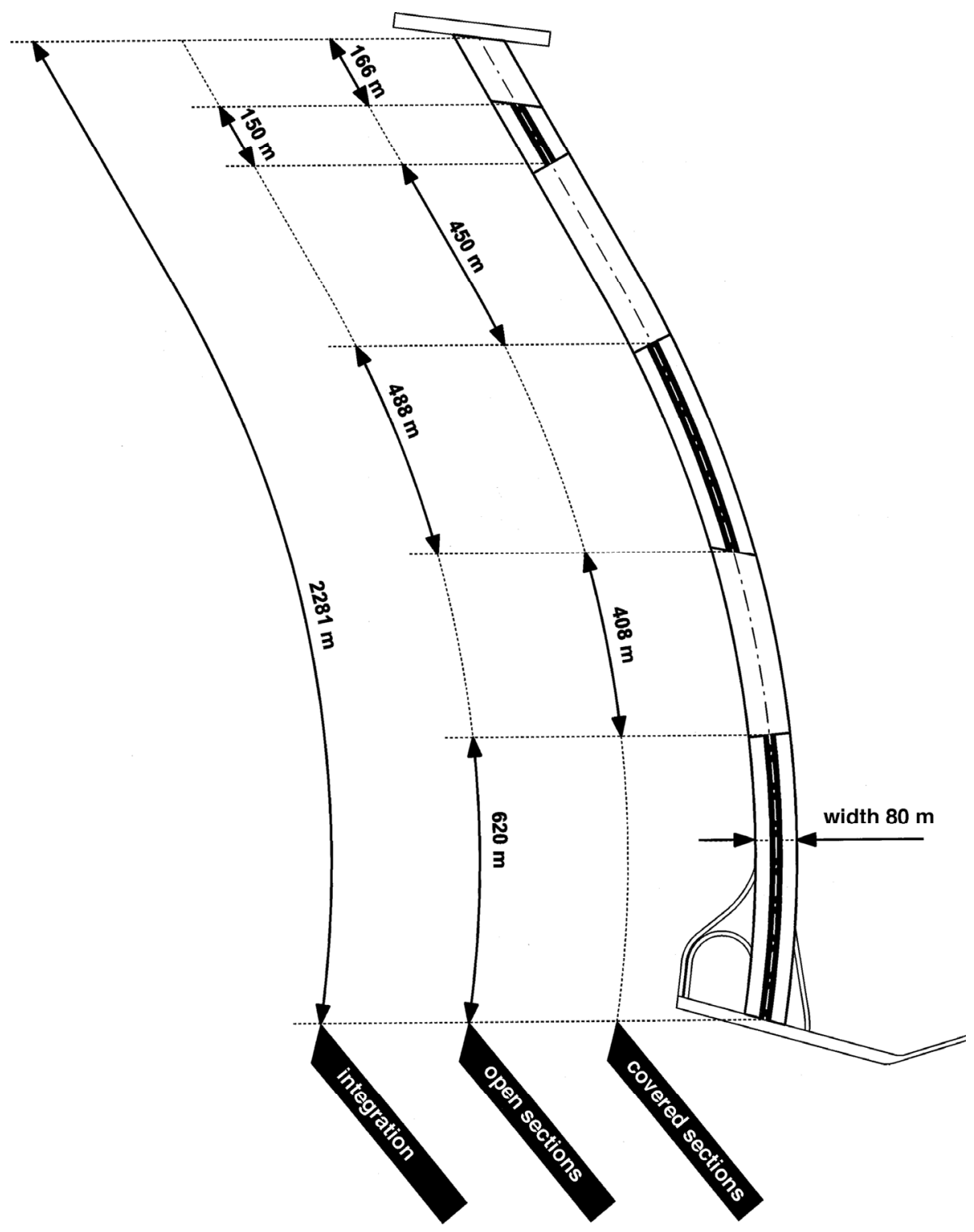

Fig. 7. Creative Alternative: alignment (Maxwan, 1998). 


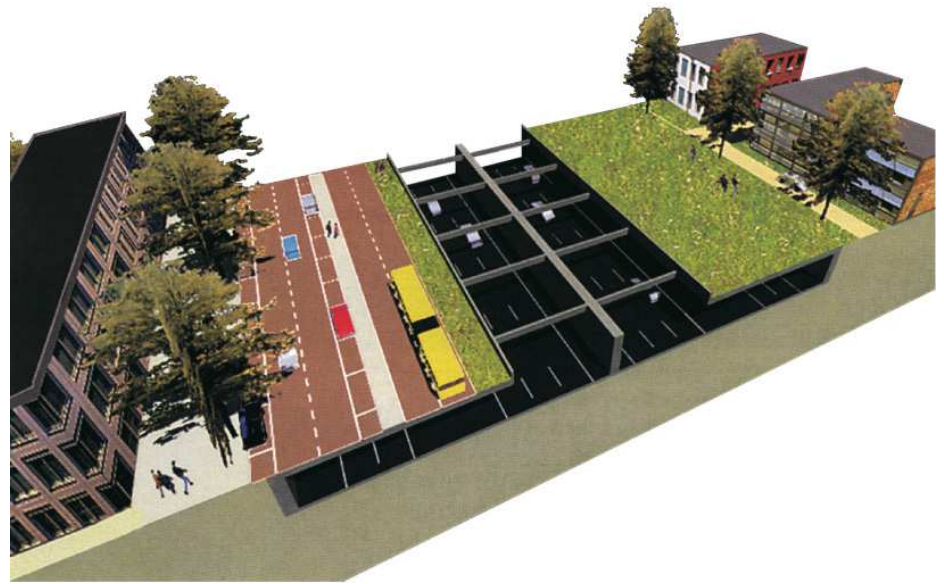

Fig. 8. The Creative Alternative with horizontal cantilevers (Maxwan, 1998).

In 1998, the Projectbureau Leidsche Rijn published an additional investigation into the requirements to integrate the A2 in Leidsche Rijn from an urban perspective (Maxwan, 1998). The project bureau's objective was to optimise the Creative Alternative. Its report contained, among other things, the results of two interesting partial studies.

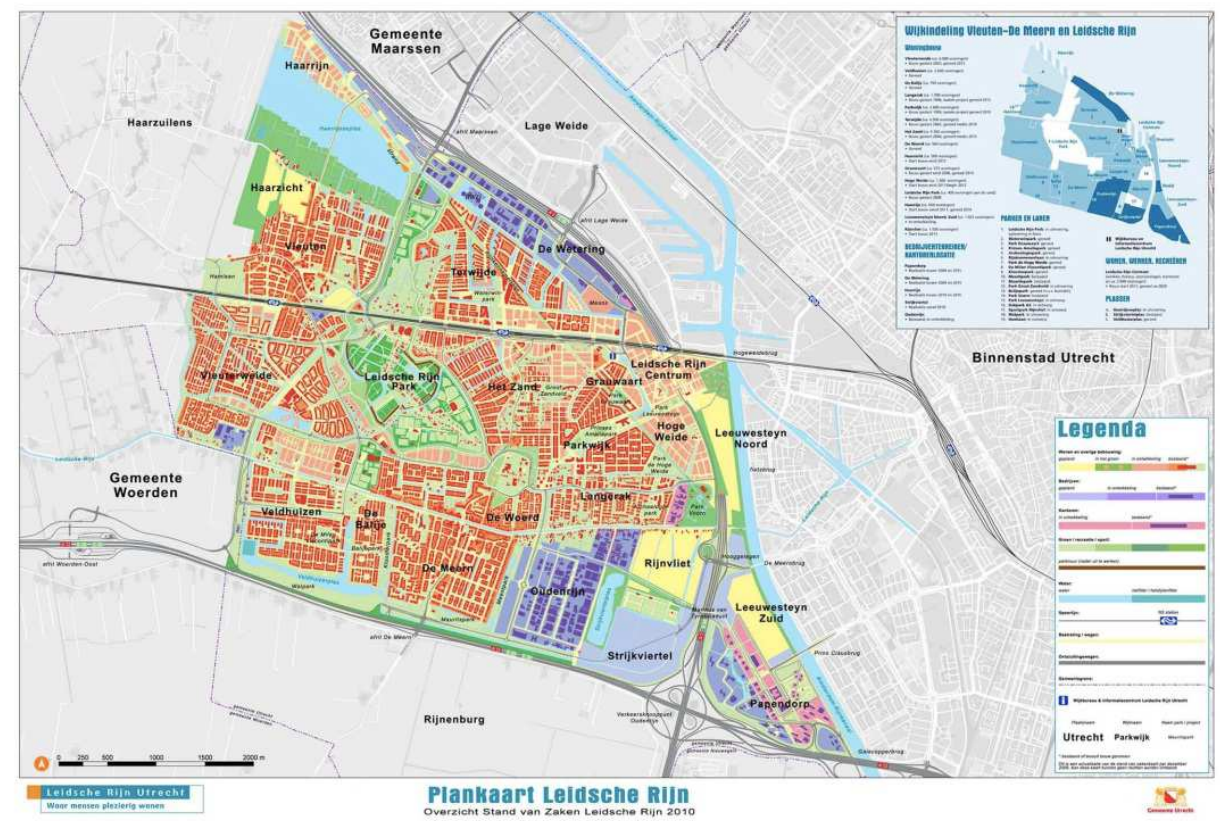

Fig. 9. Masterplan Leidsche Rijn (Utrecht, 2011). 


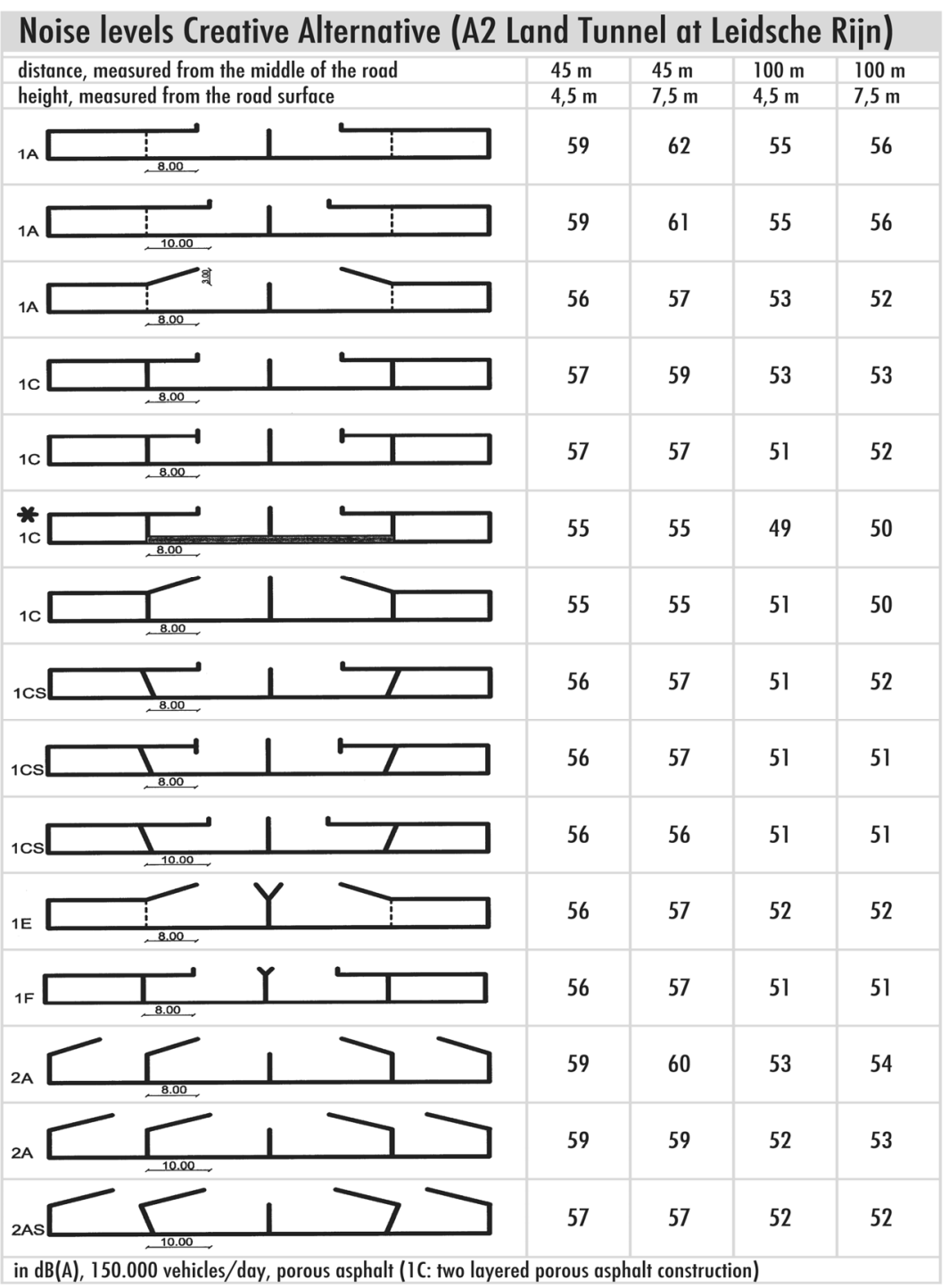

Fig. 10. Noise levels of the Landtunnel Utrecht using different sets of noise barriers and cantilevers, image by TNO (Maxwan, 1998).

The first study (conducted by TNO) looked at the noise production of the motorway and the impact of using different sets of noise barriers and cantilevers. It appeared that the use of a two-layered porous asphalt construction in combination with horizontal cantilevers promised the best results. 


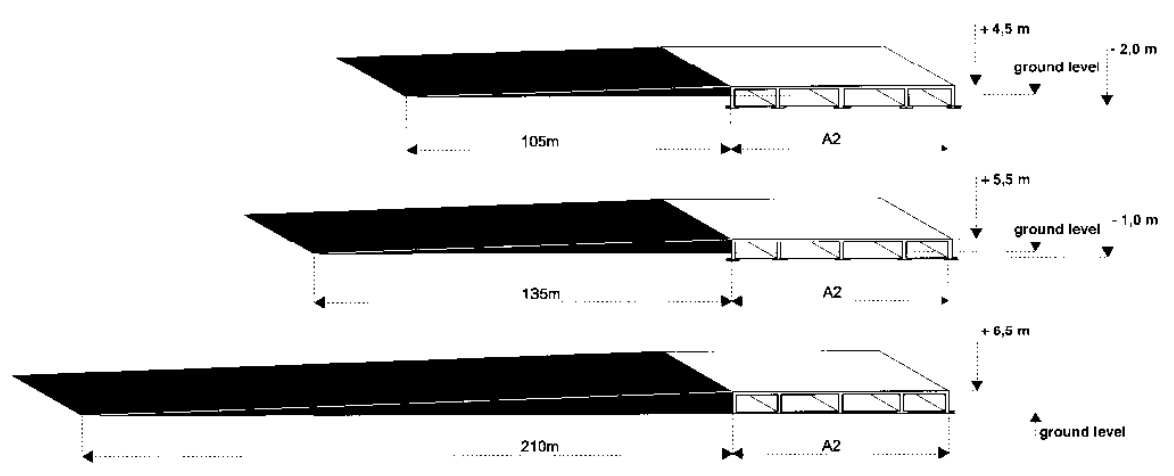

Fig. 11. Sloping as a means to integrate the Landtunnel Utrecht at Leidsche Rijn (Maxwan, 1998).

The other, somewhat simple, study visualised the use of sloping as a means to integrate the 'hollow dike' with its surrounding area. The study concluded that, along the motorway, a slope with an angle of three percent and a length of 210 metres was necessary to minimise the impact of the height difference introduced by the physical height of the land tunnel. The extensive slope was required to facilitate soft modes of transportation (walking and cycling) between the VINEX-development and the city of Utrecht. The exploration also showed that a partially submerged tunnel could do with half of that sloping area, or 105 metres.

\section{Green Link A15}

In a parallel process, the municipality of Rotterdam also called for a multifunctional tunnel to cover a section of the A15 motorway in 1998: the Green Link. The situation is comparable as the A15 separates Rotterdam from its largest VINEX development: Carnisselande. The A15 is a section of the Rotterdam Ring that connects the Rotterdam harbour area to its hinterland. The municipality of Rotterdam faced a similar line of argument as that by Utrecht. The regional Directorate General for Public Works and Water Management (RWS Zuid-Holland) told the urban planning department of the Municipality of Rotterdam that a tunnel would not be feasible because of the need to transport dangerous goods along the A15. RWS Zuid-Holland only allowed small tunnel sections of 80 metres, with a minimal spacing of 50 metres between covered sections. Rotterdam called in the support of the Delft University of Technology (TU Delft). The city was not convinced that the construction proposed by RWS Zuid-Holland could effectively reduce the environmental impact of the A15 motorway that had to be extended to five lanes in each direction. It requested an indepth investigation into the safety issues regarding motorway tunnels. The A15 presented an ideal showcase. The A15 accommodates an enormous volume of dangerous goods that flow directly from the (petro) chemical industry in the Rotterdam Mainport. There are 200,000 transports yearly, which greatly exceeds the volume that passes Leidsche Rijn. If a solution could be found here, it would be a true breakthrough. This pilot programme required TU Delft to develop regular exchanges with Rotterdam's Urban Planning Department, the Construction Department of the Directorate General for Public Works and Water Management (RWS Bouwdienst) and the Rotterdam Fire Brigade. 
The Rotterdam Fire Brigade proposed implementing a sprinkler system in the tunnel to rule out the development of any scenario that starts with a regular fire and could potentially develop into a more severe accident. In addition, TU Delft proposed containing the impact of any explosive scenario by physically separating the tunnel's tubes. Unfortunately the models that were used at that time to assess tunnel safety in the Netherlands did not allow the incorporation of any claims about the effectiveness of a sprinkler system or an improved tunnel tube configuration. Though potentially effective in practice, these measures had no impact on the outcome of the assessment itself. To influence the assessment's outcome, it appeared more important to consider the likely, but less extreme, scenarios in which regular trucks were involved, such as a 'large vehicle fire'. Isolating lorries in a separate tube from the rest of the traffic results in a notable reduction in the number of deaths due to such events, offsetting the increased mortality in the case of unlikely but more extreme events. Given that the new tunnels were built on land, it seemed that the potential economic risk was manageable as well. In the unlikely scenario that the roof is blown off, the infrastructure could be 'easily' repaired. Because urban tunnels are not situated under water, they are unlikely to lose their functionality as a small 'polder' (Hoeven, 1999). The RWS Bouwdienst provided the calculations and confirmed that the concept was sound (Rijkswaterstaat Bouwdienst, 1998). The Rotterdam Fire Brigade formulated requirements for a Category- 0 tunnel. This concept did not ban the transportation of any type of dangerous goods through the tunnel but emphasised the necessity of prevention and automated repression (Broekhuizen, 1998).

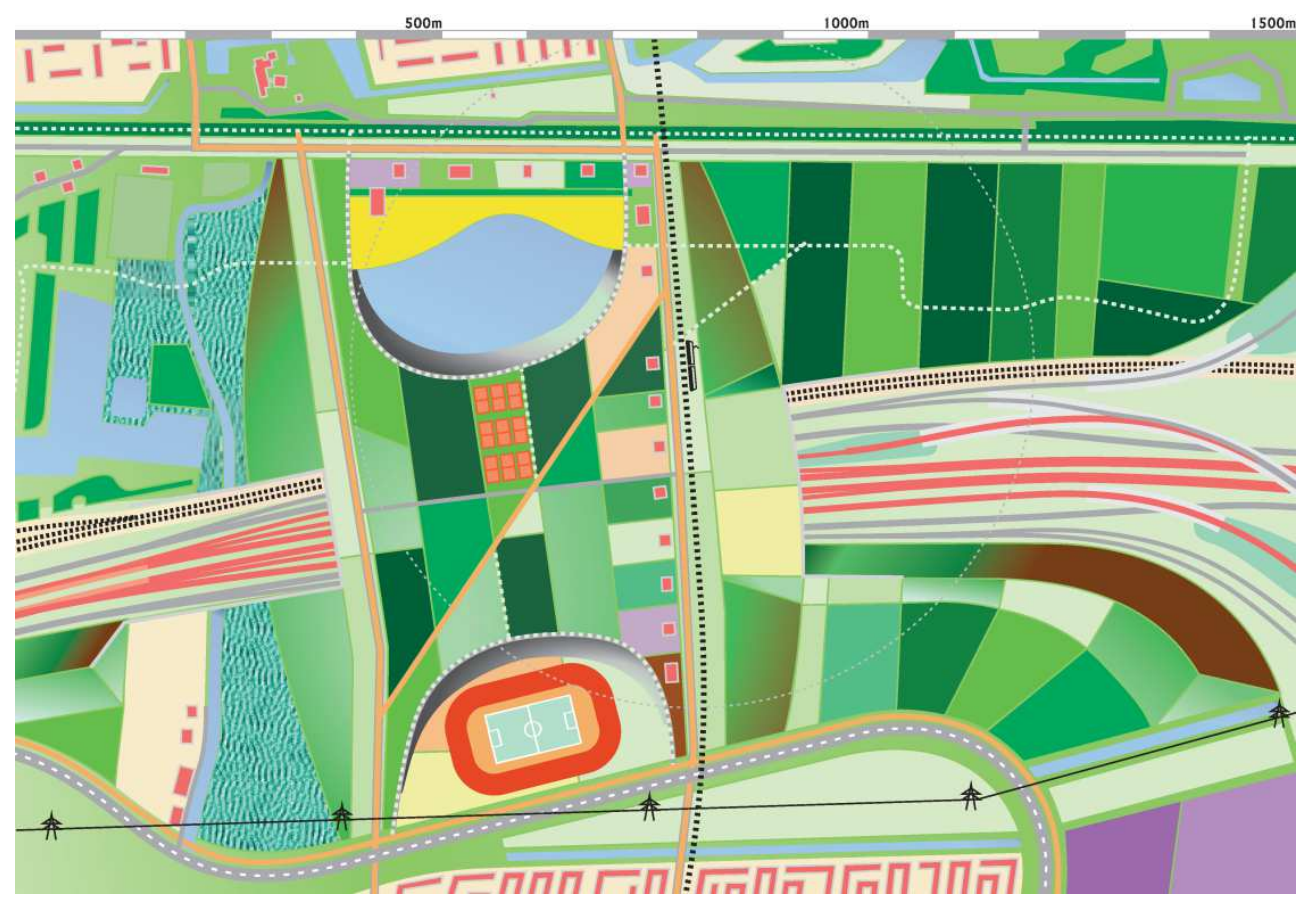

Fig. 12. Green Link A15 (Hoeven, 1999) 
Although the Green Link was ultimately not built, the publication of the concept by TU Delft, including the results of RWS' own analysis and the Category- 0 requirements by the Rotterdam Fire Brigade, made it clear for the first time in the Netherlands that transport of dangerous goods does not rule out the implementation of multifunctional tunnels. That insight was still contested by the Directorate-General for Freight Transport of the Ministry of Transport, Public Works and Water Management at that time. The issue continued to assert pressure on proposed multifunctional tunnels, such as the Landtunnel Utrecht.

\section{Weighing five alternatives followed by a final concept revision}

In the year 2000, new EU regulations on air quality were introduced and caused a stir in the Netherlands. Much of the country suffered from high levels of background pollution that were near or above the future limits set by the EU. Those limits were easily exceeded near major motorways or other sources of air pollution. The technology institute TNO delivered the first set of air quality calculations (nitrogen dioxide and particulate matter) for the A2 based on the new requirements. The calculations showed that wider than expected areas along the open parts of the land tunnel at Leidsche Rijn could not be used for residential purposes. This would mean a significant breach of the urban quality of the area and an undesirable decrease in the number of housing units that could be built. The municipality of Utrecht, the project bureau Leidsche Rijn, RWS and the Ministry of Housing, Spatial Planning and the Environment jointly commissioned a study by ARCADIS and the Architectengroep. The final report of that study was delivered in December 2001 (Brouwer, Rijnboutt, 2001). Three partial studies by TNO and ARCADIS were included in the study that investigated air pollution, safety and noise. The study unexpectedly concluded that noise was the environmental impact with the largest consequences for land use in Leidsche Rijn, rather than air quality or safety. The ARCADIS/Architectengroep study evaluated five alternatives: 1] the original 'Creative Alternative', 2] the 'Creative Alternative' with horizontal cantilevers over the road, 3] an alternative that covered only the northern part of the alignment, 4] an alternative based on short tunnels with lengths of just 80 metres, 5] a fully covered surface tunnel.

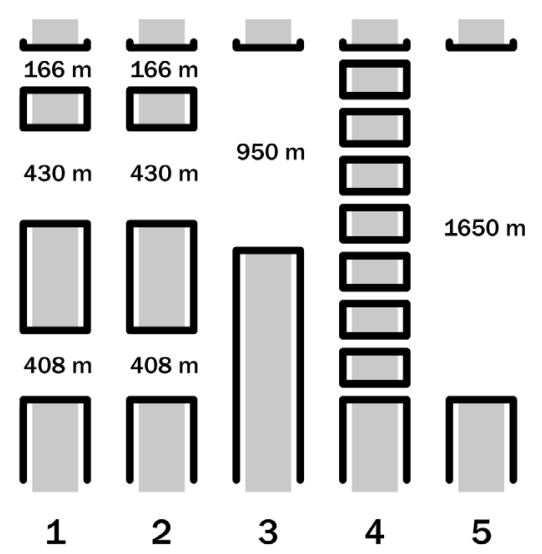

Fig. 13. Alternatives 1, 2, 3, 4 and 5 (van der Hoeven, 2010). 
The new air quality assessment by TNO provided detailed insight in the diffusion of the emissions in the project area (TNO MEP, 2001). With more experience under the new regulations and an adjusted value for the background emission, each of the alternatives seemed to keep the nitrogen dioxide values below $40 \mu \mathrm{g} / \mathrm{m}^{3}$ at a distance of 50 metres from the road. Only the 1650-m long full-length tunnel (alternative 5) showed a small area where emissions peaked at $41 \mu \mathrm{g} / \mathrm{m}^{3}$. Presented in this chapter are the nitrogen dioxide diagrams for alternatives 1, 2, 3 and 5. Alternative 4 is not presented because it was not evaluated in the TNO study. TNO calculated emission levels at distances of 50 and 100 metres from the road. No calculations were made for the area above the tunnel. The fact that no emissions are displayed here does not mean that the area is not exposed. The impact of the noise barriers was taken into account in the study.

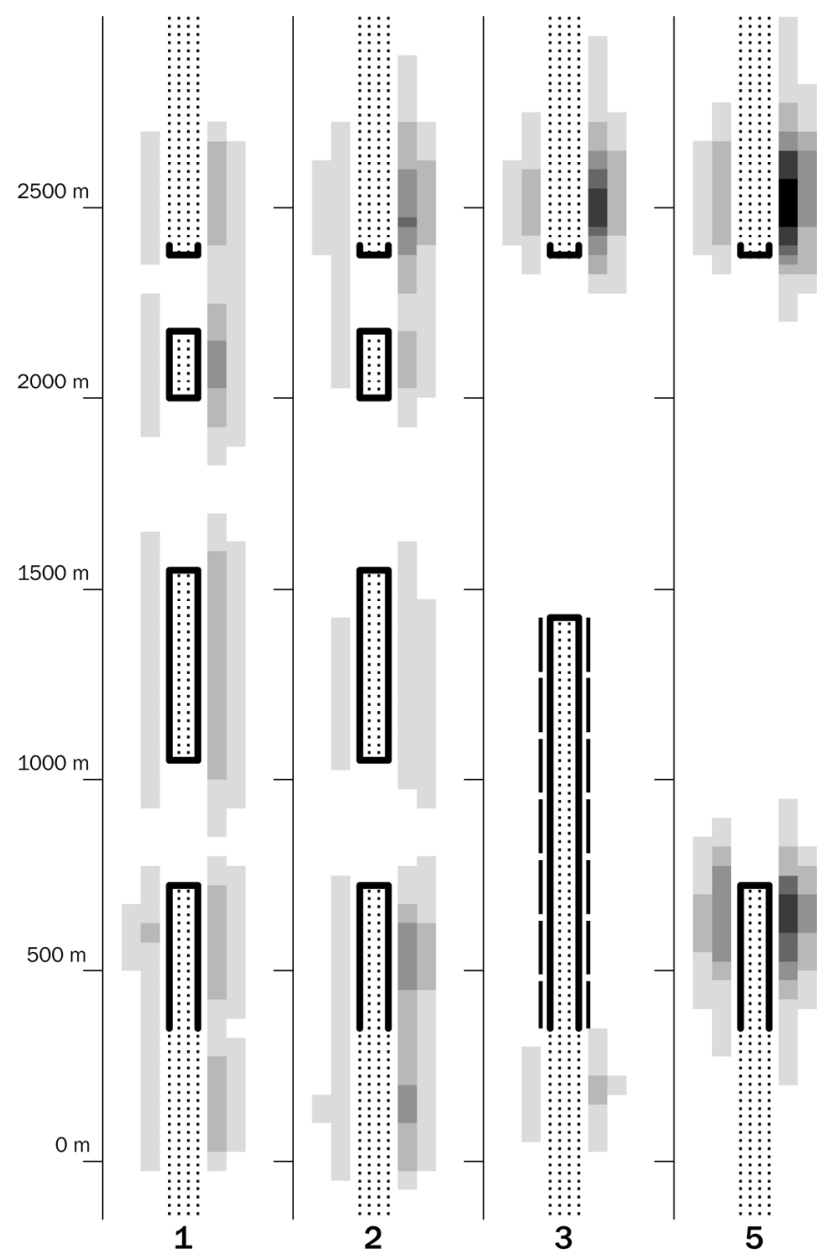

Fig. 14. Calculated nitrogen dioxide emissions alternatives 1, 2, 3 and 5 (van der Hoeven, 2010). 
Wind does seem to have an impact, which can be seen in the higher concentrations on the east side of all alternatives. The length of the tunnel matters as well. The concentration of air pollution at the ends of the tunnel increases as the tunnel becomes longer. Two walls separate in alternative 2 the inside lanes from the outside lanes. The inside lanes, designed for local traffic, are fully covered by the cantilevers and, with the addition of the wall, effectively enclosed in a 1650 meters long tunnel. Compared to alternative 1, this results in increased emissions at the tunnel's ends, and reduced emissions near the open sections. Alternative 3 contains 40-meter high buildings bordering the open sections of the motorway; this alternative effectively reduces the air pollution without creating peak concentrations like those at the other end of the tunnel.

A safety assessment was conducted by ARCADIS (ARCADIS, 2001). The ARCADIS study concludes that the existing laws and regulations, as well as the framework used in the assessment do not pose a major obstacle for any of the five alternatives. In all alternatives, the group risk that users of the motorway tunnel collectively faced stayed well below the indicative norm of 10-2/N2, despite the transport of LPG.

TNO converted its 1998 noise assessment into contours that could be displayed on maps that enabled TNO to calculate the surface of the area affected by noise levels of 50 and $55 \mathrm{~dB}$ (TNO TPD, 2001). An overview of the impact of the five alternatives on the surface of the development area, the loss of real estate revenue, and the loss of the number of housing units is presented. These figures belong to the $55 \mathrm{~dB}$ contours that require the maximal legal exemption from the Ministry of Spatial Planning, Housing and the Environment. The figures that belong to the $50 \mathrm{~dB}$ contours are considerably larger.

\begin{tabular}{|c|c|c|c|}
\hline nr. & $\begin{array}{c}\text { housing } \\
\text { units }\end{array}$ & $\begin{array}{c}\text { development } \\
\text { area }\end{array}$ & revenue \\
\hline $\mathbf{1}$ & -204 & $-3,6 \mathrm{ha}$ & $-8,2 \mathrm{M} €$ \\
\hline $\mathbf{2}$ & -145 & $-2,5$ ha & $-5,8 \mathrm{M} €$ \\
\hline $\mathbf{3}$ & -259 & $-4,5$ ha & $-10,4 \mathrm{M} €$ \\
\hline $\mathbf{4}$ & -249 & $-4,3$ ha & $-10,0 \mathrm{M} €$ \\
\hline $\mathbf{5}$ & +2 & $+0,1$ ha & $+0,1 \mathrm{M} €$ \\
\hline
\end{tabular}

Fig. 15. Table indicating lost development area, lost housing units and lost real estate revenue because of noise levels that exceed the $55 \mathrm{~dB}$ limit for each alternative (van der Hoeven, 2010).

The study also provided investment figures. The differences in the construction costs of the alternatives appear to be relatively small. The original Creative Alternative was estimated to cost $460 \mathrm{M} €$, while the optimised Creative Alternative (using horizontal cantilevers, as favoured by the Projectbureau Leidsche Rijn) was estimated to cost $501 \mathrm{M} €$ to build. A fully covered surface tunnel required an additional $10 \mathrm{M} €$ for a total of $511 \mathrm{M} €$. The fully covered 
surface tunnel would allow more residential area to be developed than the other alternatives and less development area was exposed to noise levels over 50 and $55 \mathrm{~dB}$. RWS ruled out residential development above the 13-hectare large tunnel surface, unlike the Donau-ufer Autobahn in Vienna. The full-length tunnel was, nevertheless, able to generate higher income for real estate development. Effectively, the financial differences between the optimised Creative Alternative (alternative 2) and the fully covered surface tunnel (alternative 5) disappeared altogether. The financial difference between the original Creative Alternative (alternative 1) and the fully covered surface tunnel was reduced to less than ten percent.

\begin{tabular}{|c|c|c|c|}
\hline nr. & revenue & investment A2 & $\begin{array}{r}\text { investment A2 } \\
\text { + lost revenue }\end{array}$ \\
\hline $\mathbf{1}$ & $-8,2 \mathrm{M} €$ & $460 \mathrm{M} €$ & $468 \mathrm{M} €$ \\
\hline $\mathbf{2}$ & $-5,8 \mathrm{M} €$ & $501 \mathrm{M} €$ & $507 \mathrm{M} €$ \\
\hline $\mathbf{3}$ & $-10,4 \mathrm{M} €$ & $466 \mathrm{M}$ & $476 \mathrm{M}$ \\
\hline $\mathbf{4}$ & $-10,0 \mathrm{M} €$ & $496 \mathrm{M} €$ & $506 \mathrm{M} €$ \\
\hline $\mathbf{5}$ & $+0,1 \mathrm{M} €$ & $511 \mathrm{M} €$ & $511 \mathrm{M} €$ \\
\hline
\end{tabular}

Fig. 16. Table indicating lost real estate revenue $(55 \mathrm{~dB})$, the required road investment and the sum of road investment and lost revenue for each alternative (van der Hoeven, 2010).

ARCADIS and the Architectengroep advised the decision takers to opt for any of the first three alternatives. They ruled out the alternative of a series of short tunnels that only covered a length of 80 metres because of its lacking spatial quality and the emission levels, although the TNO report did not explore this option. They also ruled out the fully covered surface tunnel because it was considered undesirable from the safety point of view, although the ARCADIS the report did not provide research-based evidence to substantiate such a claim.

In 2002, the government and the municipality of Utrecht reached a deal based on an optimised version of the Creative Alternative. The project's costs were finally assessed at 535 M€. The Ministry of Transport, Public Works and Water Management agreed to pay $323 \mathrm{M} €$. The Ministry of Housing, Spatial Planning and the Environment contributed $99 \mathrm{M} €$. The municipality, region and province of Utrecht agreed to add $83 \mathrm{M} €$ to the project's budget. Saving in other areas of the project generated an additional $30 \mathrm{M} €$. The landscaping of the surface tunnel's surrounding area could be realised with less excessive sloping (Nieuwsbank, 2002).

In 2006, just before the start of construction, the Directorate General for Public Works and Water Management and the municipality of Utrecht revised the tunnel concept one last time as they agreed to build a fully covered tunnel, without referring to potential safety or air quality issues. Meanwhile, an agreement was reached with the LPG sector to increase the 
fire resistance of the trucks that deliver LPG to gas stations, which reduces the likelihood of accidents involving these transports (Infrasite, 2006). The background levels of nitrogen dioxide and particulate matter were declining as a result of the imposed measures to meet the new European limits.

\section{Friend or foe?}

The final outcome of the Landtunnel Utrecht development may surprise. The urban planners of Maxwan had sided with the local authority of Utrecht for over a decade (19952006) in a continuous struggle with the Ministry of Transport, Public Works and Water Management in order to achieve the Masterplan Leidsche Rijn as it was originally envisioned. It faced sustained opposition from that Ministry. The Ministry however is responsible for many policy objectives and comprises many departments. Maxwan and Utrecht may have failed to recognise who is foe and who is friend in this large organisation. In the discussions the author had with the urban planners of Maxwan it became clear that the classic polarity of municipality versus ministry dominated their viewpoint.

The author was in 2000 consulted by the project manager of the regional Directorate General for Public Works and Water Management, responsible for the widening of the A2. The project manager was transparent about the fact that he opposed the overall concept of the Masterplan Leidsche Rijn. In his eyes Utrecht's compact city policy was little more than a strategy to annex its neighbouring municipality Vleuten-De Meern. However, once it would be decided to built the Landtunnel Utrecht, he felt it should be done properly as a fully covered tunnel. It should not be broken up in smaller segments or just be partially covered. The author was not at liberty to share this information with Maxwan or Utrecht.

The Construction Department of the Directorate General for Public Works and Water Management had initially raised the red flag regarding safety. The director of that Department, Rinus Olierook, chaired during this time a committee that had to initiate a large scale programme investigating multifunctional land use, a programme that would later become Habiforum. He recognised Leidsche Rijn as a perfect showcase of that principle. He made that clear in an interview that was published by the author.

\section{The bigger picture}

Looking backwards the task to unite the different viewpoints in order to reach an joint agreement seemed less daunting than the decade of moving back and fourth may suggest. What could have caused it to take so long? The introduction of this chapter sketched the larger context in which the spatial developments in the Randstad took place. The latest stage in that development (VINEX) was a time in which the larger cities like Utrecht, The Hague and Rotterdam, and smaller cities such as Eindhoven, Amersfoort and Delft broke free from the boundaries that the 1970s motorway network had imposed on them. The urban footprint of these cities expanded over the motorways. With that the network that was carefully planned to bypass cities became part of many urban areas.

The fight that enfolded in the case of Leidsche Rijn focused on details such as noise, air pollution and safety. That fight may not have been fought so hard if it did not represent a more fundamental discussion on accessibility. The motorway network was the designated 
network that would facilitate unrestricted transport of all goods and persons in all thinkable volumes. The dense grid of motorways that planners had drawn to accommodate the growing traffic was not built. Instead traffic concentrated on a few major corridors. Building homes and workplaces in these corridors exposed the population to their environmental impact. The major concern voiced by infrastructure planners was that the environmental impact could require that restrictions were imposed on specific goods and the volumes of vehicles that used these corridors. The construction of a tunnel represented more than just a local solution. Policy makers wrote in this context literally about the precedence and the irreversibility of such a solution. Unintended Leidsche Rijn may have become the poster boy of a more generic planning challenge in the Randstad.

Once the struggle was decided and it became clear that city and infrastructure had to life together, the length of the tunnel or its cover no longer mattered.

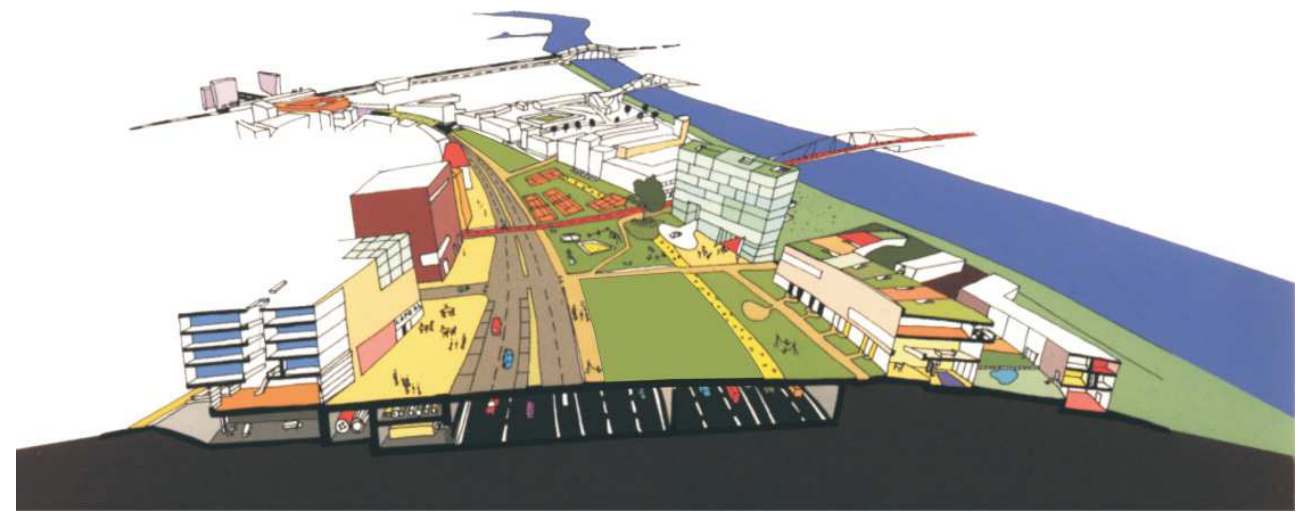

Fig. 17. Artist rendering of the Landtunnel Utrecht at Leidsche Rijn (Maxwan, 2009).

\section{Conclusion: A first of its kind}

The construction of the Landtunnel Utrecht at Leidsche Rijn signals the changing relation between the planning of infrastructure and the development of urban areas, as well as the coming of age of the Dutch multifunctional tunnel. With few references to fall back on, it took the involved stakeholders almost a decade (1995-2006) to agree that the environmental impact of an expanded A2 motorway required a landtunnel in order to develop Leidsche Rijn into a high-quality residential area for 30,000 homes. All stakeholders had to go through a collective learning process before they realised this fact. Environmental issues were intertwined with safety and financial issues for a long time, until a deal was reached on the project financing.

After more than a decade, it was decided in 2006 to construct the Landtunnel Utrecht as a 1650-m full-length covered tunnel, which resembles closely the initial concept that was included in the 1995 Master Plan. The path-finding process that took place between 1995 and 2006 required a unique and in-depth investigation into the interaction between (partly) covered tunnelling concepts, safety issues, noise production, air quality, financing, and urban development. Not all decisions were made according to the evidence that was 
produced in the process. The overall investigation can, nevertheless, be used as an evidencebased reference for the next generation of multifunctional tunnels in the Netherlands and abroad. It made clear that the motorway network in the Randstad had become an integral part of its built environment and that this fact requires new concepts and solutions.

\section{References}

ARCADIS (2001). Notitie interne en externe veiligheid Overkapping A2 Leidsche Rijn, Amersfoort

Broekhuizen, J.M. (1998). Categorie-0 tunnels, een bedreiging of oplossing? RHRR, afdeling Openbare Veiligheid, Rotterdam

Bervaes, J.C.A.M., Kuindersma, W., Onderstal, J. (2001). Rijksbufferzones verleden, heden en toekomst. Alterra Rapport 360, Wageningen, Alterra

Brouwer, F.W., Rijnboutt, K. (2001). Licht aan het eind van de tunnel, onderzoek naar de mogelijkheden tot integratie van Rijksweg A2 ter hoogte van Leidsche Rijn. ARDADIS/de architectengroep, Amersfoort/Amsterdam

Burke, G.L. (1966). Greenheart Metropolis. Planning the Western Netherlands, St. Martin's Press, New York

CBS StatLine (June 2009). Available from:

http:/ / statline.cbs.nl/StatWeb/publication/?DM=SLNL\&PA=7530NR\&D1=0\&D2

$=1-2 \& D 3=a \& H D R=T, G 1 \& S T B=G 2 \& V W=T$

Hall, P. (1966, 1977, 1983). The World Cities, World University Library, Weidenfeld \& Nicolson, London

Maxwan (1998). Over Wegen, Programma van Wensen Integratie A2, concept. Projectbureau Leidsche Rijn, Utrecht

Maxwan (June 2009). Leidsche Rijn under construction. Available from: http://www.maxwan.com/section/news/id/21/

Directie Transportveiligheid (1997). Externe veiligheid vervoer gevaarlijke stoffen. Ministerie van Verkeer en Waterstaat, Directoraat-Generaal Goederenvervoer, The Hague

Hoeven, F.D. van der (1999). de ontbrekende schakel, een veilige overkluizing van de A15, Dienst Stedebouw + Volkshuisvesting Rotterdam

Hoeven, F.D. van der (2002). RingRing, Ondergronds bouwen voor meervoudig ruimtegebruik boven en langs de Ring Rotterdam en de Ring Amsterdam, 010 Publishers, Rotterdam

Hoeven, F. van der (2010). Landtunnel Utrecht at Leidsche Rijn: the conceptualisation of the Dutch multifunctional tunnel. Tunnelling and Underground Space Technology incorporating Trenchless Technology Research, Vol 25, Elsevier, Exeter, pp. 508-517

Infrasite (June, 2009). Utrecht wil gesloten overkapping A2 bij Leidsche Rijn. Available from: http:/ / www.infrasite.nl/news/news_article.php?ID_nieuwsberichten=3514\&lang uage $=$ nl

Molag, M. (1998). Conceptueel risico-analyse model voor transport door wegtunnels rapport, N 110-03, CUR/COB, Gouda

Nieuwsbank, (June 2009). Utrecht krijgt gewenste overkapping A2 bij Leidsche Rijn. Available from: http://www.nieuwsbank.nl/inp/2002/03/07/E047.htm 
Pieterse, N., van der Wagt, M., Daalhuizen, F., Piek, M., Künzel, F., Aykaç, R. (2005). Het gedeelde land van de Randstad. Ontwikkeling en toekomst van het Groene Hart, NAi Uitgevers, Rottterdam

Projectbureau Leidsche Rijn (1996). Leidsche Rijn Utrecht, Ontwikkelingsvisie, Municipality Utrecht and Municipality Vleuten-De Meern.

Projectbureau Leidsche Rijn (1995). Masterplan Leidsche Rijn, Toelichting, Municipality Utrecht and Municipality Vleuten-De Meern.

Rijkswaterstaat Bouwdienst (1996). Notitie creatieve variant integratie A2 / Leidsche Rijn. Ministerie van Verkeer en Waterstaat, Directoraat-Generaal Rijkswaterstaat, The Hague.

Rijkswaterstaat Bouwdienst (1998). RW 15 Integratiestudie 'de Ontbrekende Schakel' rapport, Vergelijking In- en Externe Risico Tunnelvarianten. Rijkswaterstaat, Utrecht.

Rijkswaterstaat (June 2009). Landtunnel Utrecht. Rijkswaterstaat. Available from: www.rijkswaterstaat.nl/images/Factsheet\%20Landtunnel\%20Utrecht_tcm174167562.pdf

TNO MEP (2001). Onderzoek naar de effectiviteit van maatregelen ter beperking van de NO2 en fijn stof concentraties bij de A2-doorsnijding van Leidsche Rijn, Apeldoorn

TNO TPD (2001). Geluidcontouren Leidsche Rijn, Delft

VROM (1988). Vierde nota over de ruimtelijke ordening: op weg naar 2015. Deel d: regeringsbeslissing. Ministerie van Volkshuisvesting, Ruimtelijke ordening en Milieu, SdU, The Hague

VROM (1993). Vierde nota over de ruimtelijke ordening extra, deel 4: Planologische kernbeslissing nationaal ruimtelijk beleid, SdU, The Hague

VROM, LNV, V\&W and EZ (2004). Nota ruimte. Ruimte voor ontwikkeling. Ministerie van Ministerie van Volkshuisvesting, Ruimtelijke Ordening en Milieu, Ministerie van Landbouw, Natuurbeheer en Visserij, Ministerie van Verkeer en Waterstaat and Ministerie van Economische Zaken, SdU, The Hague

V\&RO (1966). Tweede nota over de ruimtelijke ordening in Nederland. Ministerie van Volkshuisvesting en Ruimtelijke Ordening, SdU, The Hague

V\&RO $(1976,1977)$. Derde Nota over de Ruimtelijke Ordening in Nederland, Deel 2a en Deel 2d (Report on Urban Development, SdU, The Hague 


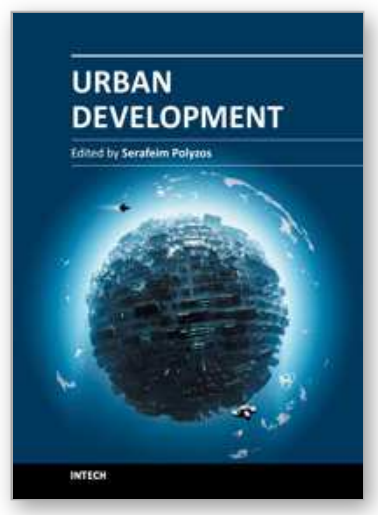

\author{
Urban Development \\ Edited by Dr. Serafeim Polyzos
}

ISBN 978-953-51-0442-1

Hard cover, 296 pages

Publisher InTech

Published online 30, March, 2012

Published in print edition March, 2012

Cities are growing as never before and nowadays, it is estimated that at least $50 \%$ of the world's population lives in urban areas. This trend is expected to continue and simultaneously the problems in urban areas are anticipated to have an increase. Urbanization constitutes a complex process involving problems with social, economic, environmental and spatial dimensions that need appropriate solutions. This book highlights some of these problems and discusses possible solutions in terms of organisation, planning and management. The purpose of the book is to present selected chapters, of great importance for understanding the urban development issues, written by renowned authors in this scientific field. All the chapters have been thoroughly reviewed and they cover some basic aspects concerning urban sustainability, urban sprawl, urban planning, urban environment, housing and land uses. The editor gratefully acknowledges the assistance of Dr Marius Minea in reviewing two chapters.

\title{
How to reference
}

In order to correctly reference this scholarly work, feel free to copy and paste the following:

Frank van der Hoeven (2012). Leidsche Rijn: Balancing the Compact City with the Randstad Motorway Network, Urban Development, Dr. Serafeim Polyzos (Ed.), ISBN: 978-953-51-0442-1, InTech, Available from: http://www.intechopen.com/books/urban-development/leidsche-rijn-balancing-the-compact-city-with-therandstad-infrastructure-network

\section{INTECH}

open science | open minds

\section{InTech Europe}

University Campus STeP Ri

Slavka Krautzeka 83/A

51000 Rijeka, Croatia

Phone: +385 (51) 770447

Fax: +385 (51) 686166

www.intechopen.com

\section{InTech China}

Unit 405, Office Block, Hotel Equatorial Shanghai No.65, Yan An Road (West), Shanghai, 200040, China 中国上海市延安西路65号上海国际贵都大饭店办公楼405单元 Phone: +86-21-62489820

Fax: $+86-21-62489821$ 
(C) 2012 The Author(s). Licensee IntechOpen. This is an open access article distributed under the terms of the Creative Commons Attribution 3.0 License, which permits unrestricted use, distribution, and reproduction in any medium, provided the original work is properly cited. 